\title{
Om korrektur
}

Det siste du som forfatter gjør før du sender en vitenskapelig artikkel til redaksjonen for publisering, er å korrekturlese den.

\section{Forfattere}

Susanne Dietrichson

Journalist

Signe Marie Flåt

Manusredaktør og redigerer

Sykepleien

Sykepleien Forskning 2013 8(2)(169-171)

DOI: https://doi.org/10.4220/sykepleienf.2013.0072

Det er viktig med en grundig korrektur, først fra

forfatterens side og deretter fra redaksjonen.

Forfatteren må være sikker på at tabeller og figurer

ikke mangler eller inneholder feil. Det er også viktig at

forfatteren sjekker alle referansene nøye. Forfatteren

skal også ha foretatt en grundig korrektur i henhold til

forfatterveiledningen.

For å gi manusforfattere og lesere innsikt i hvordan kvalitetssikringen av våre forskningsartikler foregår, har vi valgt å beskrive hvordan vi jobber med språkvask og korrekturlesing av stoffet vi publiserer.

\section{Best mulig}


Alt stoffet i Sykepleien Forskning går gjennom flere runder med språkvask og korrektur. Målet er å publisere artikler uten skrivefeil, men uansett hvor mange øyne som ser, virker det nærmest som en naturlov at en og annen liten (eller stor) feil blir oversett. Flere runder med systematisk korrektur gir oss i hvert fall best mulig resultat.

Hovedansvaret for den språklige korrekturen ligger hos redaksjonen, men også forfatterne av forskningsartiklene får tilsendt artiklene til en siste korrektursjekk før de publiseres. Det er forfatterens ansvar å sørge for at innholdet er korrekt.

\section{Fagfeller}

Alle forskningsartiklene som publiseres i Sykepleien Forskning, blir sendt til vurdering hos fagfeller etter at redaktøren har lest gjennom manuset. Fagfellenes oppgave er hovedsakelig å kommentere det faglige innholdet, men enkelte av dem retter også skrivefeil.

Etter at manuset har vært hos fagfeller, blir det revidert av forfatter, som sender det tilbake til redaktør. Hvis det er snakk om store endringer, blir manuset gjerne sendt tilbake til forfatter for en andre eller tredje runde med justeringer. Deretter blir revidert versjon sjekket av statistiker ved behov, og endelig godkjent for publisering. Publiseringsklart manus blir deretter overtatt av manusredaktør, som «desker» manuset.

\section{Desking}

Desking innebærer språkvask og redigering. Vi retter selvsagt stavefeil, inkonsekvenser og grammatiske feil samt skriver om vanskelige eller uklare setninger. 
Sykepleien Forskning har en språklig mal som vi

følger for alt vi publiserer. Det innebærer blant annet at alle manuskripter rettes med et elektronisk korrekturprogram. Programmet kan likevel ikke erstatte det menneskelige øyet. Hvis det for eksempel står «hest» når det egentlig skal stå «helt», vil programmet ikke rette dette.

Av og til foreslår vi store endringer, for eksempel å erstatte et sentralt begrep med et annet, endre en setning fullstendig eller slette noe. Store endringer diskuterer vi med forfatteren som er oppgitt som kontaktperson, i form av merknader i manuset. Små justeringer, som for eksempel å rette opp skrivefeil eller å dele en spesielt lang setning i to, drøfter vi ikke med forfatteren underveis.

Vi prøver også gjennomgående å gjøre språket mer aktivt (les også: $\AA$ se sin egen tekst utenfra).

Forfatteren får tilsendt språkvasken til godkjenning i en Word-fil med eventuelle merknader å ta stilling til.

\section{Forfatterkorrektur}

Hvis forfatteren ser endringer som han eller hun er uenige i, kommer vi frem til en løsning som alle kan leve med. Hvis forfatteren finner feil eller retter i setninger vi har bedt vedkommende endre, bruker han eller hun funksjonen Spor endringer. Siden dette er siste versjon av manuskriptet, er det viktig at forfatteren ikke endrer annet enn det han eller hun er blitt bedt om å endre.

\section{Klargjøring for publikasjon}

Når vi har fått tilbake godkjent manus fra forfatteren, klargjør vi manuset for publisering. Her innebærer deskingen at vi ofte lager nye titler på artiklene, hovedsakelig fordi forfatternes forslag er for lange, uklare eller fordi vi mener vårt forslag vil gjøre dem mer søkbare på nettet. 
Vi kommer også med forslag til nye mellomtitler hvis disse er for lange eller det er for få av dem. Vi finner et bilde vi mener illustrerer artikkelen godt, og skriver en passende bildetekst. I tillegg trekker vi ut gode sitater og skriver en innledende tekst (ingress).

Hvis manuskriptet inneholder tabeller og figurer, blir disse tegnet av våre grafiske designere.

Når manuset er ferdig redigert, sendes det i PDFformat til forfatteren. Forfatteren får en siste sjanse til å sjekke at alt er på plass, at tabeller og figurer er blitt korrekte samt lese raskt gjennom en siste gang.

Siden alle tabeller og figurer blir tegnet helt på nytt av våre grafiske designere, hender det at disse har feil eller mangler, for eksempel en kolonne som har forskjøvet seg, et komma som står på feil sted, eller opplysninger som har falt ut. Derfor ber vi alltid om at tabeller og figurer sjekkes ekstra nøye av forfatter, som har førstehåndsinformasjon om hvordan de skal se ut og hva de skal inneholde.

På dette stadiet er det kun feil som kan rettes siden manuskriptet er så godt som ferdig. Forfatteren melder inn eventuelle feil og mangler ved artikkelen til manusredaktør på e-post eller telefon.

Manusredaktøren implementerer rettelsene i den publiseringsklare artikkelen og foretar en siste korrekturlesing. Så blir artikkelen publisert på Sykepleien.no/forskning. 